Editorial

\title{
Sustainable Development Agenda 2030 thrives on health
}

\author{
Z. Mirza ${ }^{1}$
}

Never before has the flight of human imagination made calls for universal development that are so loud and audacious. The all-encompassing Sustainable Development Agenda 2030 (SD Agenda 2030) has evolved over 67 years since the adoption of the Universal Declaration of Human Rights by the United Nations in 1948. Although based on the same principle of universality, the scope of the Agenda is much broader. It is a melting-pot of human rights, environmental movements and the fight against poverty; hence, it is a plan of action for people, the planet and prosperity. Moreover, it also seeks peace as a necessary condition for development.

The symbiotic relationship between health and development is well understood. The historic Alma-Ata Declaration on Primary Health Care in 1978 (1) and the work of the WHO Commission on Social Determinants of Health (2) have unequivocally established that for health to be attained there is a need for "action of many other social and economic sectors in addition to the health sector" (1). The more recent work on health-in-all-policies approach (3) is also embedded in the importance of inter-sectoral action to protect and promote health.

The centrality of health in the SD Agenda 2030 is evident through the links that the Sustainable Development Goal 3 (SDG3) has with the remaining 16 SDGs. SDG3 aims to "Ensure healthy lives and promote well-being for all at all ages" (4) and its 13 targets cover practically all aspects of current health issues, including the need to strengthen health systems. Target SDG3.8 is bold in terms of its scope, namely "achieve universal health coverage, including financial risk protection, access to quality essential health-care services and access to safe, effective, quality and affordable essential medicines and vaccines for all" (4).

The interdependence of SDGs is highlighted through SDG3 and its relationship with the other 16 SDGs, which are: poverty, hunger, education, gender equality, water and sanitation, energy, economic growth, inclusive and sustainable industrialization and innovation, inequality, safe cities, sustainable consumption and production, climate change, sustainable use of water reservoirs, environmental protection, peace and justice, and partnerships. Health will benefit from development in each of these areas, just as health also contributes to the advancement towards these goals. For example, when poverty is reduced there are fewer incidences of poverty-related diseases, and citizens are able to spend more on their health. Thus, healthy individuals are able to work more, earn better wages and enjoy economic prosperity. Such health benefit-contribution relationships exist for all other goals.

On 25 September 2015, the General Assembly of United Nations adopted Resolution 70/1 titled "Transforming Our World: the 2030 Agenda for Sustainable Development" (4).
Never before had such a bold ambition embraced the aspirations of all citizens sharing the planet, given that the Resolution mandated for all United Nations (UN) members take action on this Agenda. Clearly such an array of goals is not within the competencies and bounds of a single agency; thus, intersectoral action and partnerships were made part of the agenda itself, resulting in the 17th SDG, titled "Strengthen the means of implementation and revitalize the Global Partnership for Sustainable Development" (4). In addition, an elaborate framework of 230 indicators has been developed by the Inter-Agency and Expert Group (IAEG) on SDG Indicators to monitor progress in implementation of this action plan for global transformation (5). Totaling 26 indicators, the health goal has the largest number of proposed indicators of all 17 SDGs. Unlike Millennium Development Goals (MDGs), which constituted a less focused agenda and was mainly donor driven (despite some remarkable achievements), the SD Agenda 2030 is the responsibility of Member States.

What does the SD Agenda 2030 mean to governments and development partners, and how can they work in partnership to support it? This is the important question being addressed by both sides. The comprehensive nature of the Agenda is such that either national development planning commissions/ministries, or their equivalent pivotal bodies, have to take on the leadership role and coordinate, or this work must be led by the prime ministerial/ 
presidential offices. Likewise, development partners must also break their "silo" approach and work at an interagency level. SD Agenda 2030 requires a holistic governmental approach, which demands financing and strong leadership, whereby national development visions have to align with SDGs. World Health Organization (WHO) is leading on SDG3 and actively developing the required institutional arrangements for this substantial undertaking.

Thus, the SDG agenda remains a major driving force behind much of
WHO's work, and has implications for priorities and working practices throughout the Organization. How the currentgeneration of developmentpractitioners lived up to achieving the grand mission agreed in September 2015 will be judged by future generations.

\section{References}

1. Declaration of Alma-Ata. International Conference on Primary Health Care. Alma-Ata, USSR, 6-12 September, 1978 (http:// www.who.int/publications/almaata_declaration_en.pdf).

2. Commission on Social Determinants of Health (CSDH). Closing the gap in a generation: health equity through action on the social determinants of health. Final Report of the Commission on Social Determinants of Health. Geneva: World Health Organization; 2008 (http://apps.who.int/iris/bitstre am/10665/43943/1/9789241563703_eng.pdf).

3. European Observatory on Health Systems and Policies. Health in all policies, seizing opportunities, implement- ing policies. Helsinki: Ministry of Social Affairs and Health, Finland; 2013 (http://www.euro.who.int/_data/assets/ pdf_file/0007/188809/Health-in-All-Policies-final.pdf).

4. Resolution A/RES/70/1. Transforming our world: the 2030 agenda for sustainable development. United Nations General Assembly $70^{\text {th }}$ session; New York: United Nations; 25 September 2015 (https://sustainabledevelopment.un.org/post2015/ transformingourworld)

5. Sustainable Development Goal indicators. New York: United Nations Statistics Division (http://unstats.un.org/sdgs/). 